\title{
EFEKTIVAS PENGGUNAAN PADLET PADA PEMBELAJARAN DARING
}

\author{
Astuti *", Almas Adlina ${ }_{2}$, Fitria Mayasari ${ }^{3}$, Inke Nur East Borneo ${ }^{4}$, Ismayanty 5 Venina \\ Sinaga ${ }^{\circ}$, \\ Pendidikan Matematika, Fakultas Pascasarjana UNIMED, Medan Indonesia \\ bundaziazam09@gmail.com・, almasadlina4321@gmail.com² , \\ fitriamayasari1205@gmail.com ${ }^{3}$ eastborneo28gmail.com 4 , ismayanty96gmail.coms \\ veninasinaga145@gmail.com。
}

\begin{abstract}
ABSTRAK
Tujuan penelitian ini adalah :1) mengetahui pengetahuan mahasiswa sebelum dan setelah diberikan perlakuan pembelajaran dengan menggunakan aplikasi padlet, 2) mengetahui pengetahuan mahasiswa sebelum dan setelah diberikan perlakuan pembelajaran tanpa penggunaan aplikasi padlet, 3) mengetahui perbedaan pengetahuan mahasiswa yang diberi perlakuan pembelajaran dengan menggunakan media pembelajaran digital dengan mahasiswa yang pembelajaran tanpa menggunakan aplikasi padlet, 4) mengetahui besarnya efektivitas aplikasi padlet dalam meningkatkan pengetahuan mahasiswa. Metode penelitian yang digunakan dalam penelitian ini adalah Quasi Experimental dengan desain penelitian Nonequivalent Control Group Design. Penelitian dilaksanakan di FMIPA Universitas Negeri Medan jurusan pendidikan matematika dimana sampel penelitian ini adalah kelas PSPM 21D (kelas control) dan PSPM 21F (kelas eksperimen) secara berurutan berjumlah 45 dan 44 mahasiswa. Hasil penelitian menunjukkan bahwa:1) Terdapat perbedaan pengetahuan mahasiswa kelas eksperimen sebelum dan setelah mengikuti pembelajaran dengan aplikasi padlet yaitu 47,38 menjadi 78,58. 2) Terdapat perbedaan pengetahuan mahasiswa kelas kontrol sebelum dan setelah mengikuti pembelajaran tanpa penggunaan aplikasi padlet yaitu 46,97 menjadi 71,23. 3) Peningkatan pengetahuan mahasiswa kelas eksperimen lebih besar atau lebih cepat daripada peningkatan pengetahuan mahasiswa kelas kontrol yaitu 78,58 > 71,23. 4). Besarnya selisih laju peningkatan kelas eksperimen lebih besar 7,35 sehingga menunjukkan penggunaan aplikasi padlet lebih efektif dari pada yang tanpa penggunaan aplikasi padlet.
\end{abstract}

Kata kunci : Padlet ; Pembelajaran Daring

\section{PENDAHULUAN}

Pada tahun 2020 seluruh dunia mengalami wabah yaitu pandemi Covid- 19. Pandemi Covid-19 adalah krisis kesehatan yang melanda hampir di seluruh penjuru dunia. Pandemi ini berdampak pada berbagai bidang termasuk di bidang pendidikan. Banyak negara memutuskan untuk sementara menutup sekolah, kampus selama masa pandemi covid-19 berlangsung. Setiap Negara membuat kebijakan-kebijakan untuk mengatasi permasalahan yang sedang terjadi. Untuk mengatasi wabah pandemi Covid -19, semua negara menerapkan sebuah tindakan yaitu dengan melakukan gerakan social distancing yaitu jarak sosial yang dirancang untuk mengurangi interaksi orang-orang dalam komunitas yang lebih luas (Wilder-Smith \& Freedman, 2020:2). Dengan adanya social distancing maka pembelajaran di semua lembaga pendidikan menjadi terhambat dan tidak bisa dilakukan secara langsung, kegiatan belajar mengajar menjadi terganggu, pembelajaran yang awalnya dilalukan secara tatap muka untuk sementara tidak bisa dilakukan. Untuk mengatasi 
permasalahan tersebut maka perlu adanya perubahan desain model pada kegiatan belajar mengajar untuk menghindari pembelajaran dengan tatap muka sebagai upaya untuk mengurangi penyebaran wabah virus covid-19. Kemendikbud mengeluarkan surat edaran No 4 tahun 2020 tentang pelaksanaan kebijakan pendidikan dalam masa darurat penyebaran corona virus disease (Covid-19) yang salah satu isinya adalah belajar dari rumah dengan kegiatan pembelajaran secara daring atau jarak jauh.

Selama pandemi berlangsung, kini pembelajaran daring telah dilakukan hampir di penjuru dunia (Goldschmidt, 2020:88). Indonesia merupakan salah satu negara yang juga melaksanakan pembelajaran daring sebagai upaya untuk mengurangi penyebaran virus Covid-19. Maka selama pandemi Covid-19 berlangsung setiap lembaga pendidikan mulai dari sekolah dasar sampai ke perguruan tinggi melaksanakan kegiatan pendidikan dengan pembelajaran jarak jauh. Pembelajaran jarak jauh, muncul pada akhir abad ke-20, memasuki abad ke-21 menjadi sebagai salah satu pembelajaran yang efektif (Lenar et al, 2014:111). Pendidikan Jarak Jauh dapat didefinisikan sebagai proses pembelajaran yang tidak memperhitungkan ruang dan waktu pembelajaran, memiliki sifat mandiri untuk proses pengembangan peserta didik menggunakan metode maupun media dalam kegiatan pembelajaran (Kor et al, 2014:854).

Dengan kegiatan pembelajaran daring mahasiswa dapat memiliki waktu yang lebih ketika belajar dan dapat belajar dengan fleksibel. Mahasiswa dapat berkomunikasi dengan guru menggunakan berbagai aplikasi seperti classroom, video conference seperti melalui googlemeet dan zoom, live chat, maupun media elearning lainnya yang disediakan masing-masing lembaga pendidikan. Akan tetapi faktanya di lapangan muncul beberapa masalah selama di adakan pembelajaran daring. Salah satu nya adalah masalah yang terjadi pada pembelajaran matematika dasar. Matematika dasar merupakan mata kuliah awal bagi mahamahasiswa matematika pada Prodi Pendidikan Matematika FMIPA UNIMED. Dari hasil observasi peneliti selama kegitan pembelajaran berlangsung di materi integral, mahamahasiswa kurang mampu menuangkan ide-ide dan merespon pada kegiatan tanya jawab dan diskusi berlangsung. Mahamahasiswa terkendala dalam mengemukakan pendapatnya karena dalam materi integral jawaban tidak bisa jika hanya dilisankan tanpa dituliskan.

Salah satu solusi untuk mengatasi masalah tersebut adalah dengan menggunakan aplikasi media pembelajaran berbasis web yaitu Padlet. Padlet merupakan aplikasi pembelajaran daring gratis berupa papan online yang dapat digunakan guru dan mahasiswa untuk menuangkan ide atau pikiran juga memposting konten pada halaman. Aplikasi Padlet telah memenuhi standar aplikasi pendidikan internasional yang disebut The International Society for Technology in Education (ISTE), lemabaga tersebut mensurvei dan menganalisis kelayakan suatu media pembelajaran. Lembaga tersebut juga membagi standarisasai mereka ke berbagai bidang Pendidikan. Antar lain kelayakan bagi peserta didik, bagi pengajar, bagi pemimpin pengajar, bagi pelatih, dan bagi edukasi pengetahuan computer. (ISTE Standards dalam jurnal Ghesta Letsari, dkk 2019). 
Aplikasi Padlet dipilih karena aplikasi ini tersedia dalam versi gratis, selain itu aplikasi ini bisa diakses melalui google, jadi tidak perlu mengunduh aplikasi ini untuk dapat menggunakannya. Penggunaan aplikasi Padlet ini juga tidak memerlukan terlalu banyak kuota. Padlet mampu menciptakan kegiatan pembelajaran yang nyata karena dosen dan mahamahasiswa berada dalam satu waktu. Fungsi aplikasi Padlet dalam pembelajaran matematika dasar ini adalah adalah sebagai tempat memberikan materi dan juga sebagai LKPD sehingga mahamahasiswa bisa langsung menuangkan ide dan mempresentasikan hasil diskusinya. Selain itu, dengan padlet dosen juga akan melihat mahamahasiswa yang aktif dalam kegiatan pembelajaran tersebut dan dapat menyimpan hasil pekerjaan mahamahasiswa. Berdasarkan paparan di atas maka peneliti tertarik untuk melakukan penelitian berjudul "Efektivitas Penggunaan Padlet dalam Pembelajaran Daring".

\section{METODE}

Penelitian ini dilakukan di kelas PSPM 21D dan PSPM 21F FMIPA Universitas Negeri Medan jurusan Pendidikan Matematika sejak bulan Oktober 2021 hingga selesai. Jenis penelitian yang digunakan dalam penelitian ini adalah penelitian kuantitatif. Menurut Sugiyono (2019: 72), metode penelitian eksperimen diartikan sebagai metode penelitian yang digunakan untuk mencari pengaruh perlakuan tertentu terhadap yang lain dalam kondisi yang terkendalikan. Desain penelitian ekperimen terbagi ke dalam tiga bentuk yaitu pre-experimental design, true experimental design, dan quasi experimental design. Dari ketiga jenis penelitian tersebut, penelitian ini secara berurut menggunakan metode penelitian dan desain penelitian yaitu eksperimen kuasi/ quasi experimental design dan Nonequivalent Control Group Design dimana kelas eksperimen maupun kelas kontrol akan dibandingkan. Kedua kelas tersebut diberikan pretes, kemudian diberikan perlakuan, dan terakhir diberikan postes.

\begin{tabular}{lccc}
\multicolumn{5}{c}{ Tabel 2.1 Desain Penelitian } \\
Nonequivalent Control Group Design \\
\hline Kelas & Pretest & Perlakuan & Posttest \\
\hline Eksperimen & O1 & $\mathrm{X}$ & $\mathrm{O} 2$ \\
Kontrol & $\mathrm{O} 3$ & - & $\mathrm{O} 4$ \\
\hline
\end{tabular}

Keterangan :

O1 : Pretest Kelas Eksperimen

$\mathrm{O} 2$ : Pretest Kelas Kontrol

O3: Posttest Kelas Eksperimen

O4: Posttest Kelas Kontrol

$\mathrm{X}$ : Perlakuan dengan menggunakan aplikasi padlet

- : Tanpa menggunakan aplikasi padlet

Populasi dalam penelitian ini adalah seluruh mahasiswa jurusan Pendidikan Matematika FMIPA Universitas Negeri Medan. Sedangkan yang menjadi sampel penelitian hanya dua kelas yaitu kelas PSPM 21 D sebagai kelas kontrol dan PSPM $21 \mathrm{~F}$ sebagai kelas eksperimen dengan jumlah mahamahasiswa secara berurutan 45 dan 
44. Pemilihan kelas pada penelitian ini dipilih berdasarkan kemampuan rata - rata prestasi mahasiswa yang dicapai hampir sama dilihat dari nilai - nilai sebelumnya

Dalam penelitian ini terdapat 2 variabel yaitu variabel bebas dan variabel terikat. Yang menjadi variabel bebas pada penelitian ini adalah penggunaan aplikasi padlet dan bertindak sebagai variabel terikat pada penelitian ini adalah pengetahuan mahamahasiswa.

Instrument penelitian yang digunakan adalah instrument berbentuk tes formatif untuk mengukur pengetahuan/prestasi mahamahasiswa. Kemudian dilakukan uji validitas dan uji reliabilitas terhadap instrument tes tersebut. Setelah itu dilakukan uji coba instrument tes terhadap subjek uji coba yang merupakan bagian populasi penelitian dengan tujuan agar keadaan subjek uji coba tersebut diharapkan betulbetul sama dengan subjek penelitian atau paling tidak mendekati keadaan yang sebenarnya. Supaya tidak bias maka subjek ujicoba diambil dari bagian populasi yang tidak dijadikan sampel penelitian.

Teknik pengumpulan data yang digunakan dalam penelitian ini adalah "Tes Pengetahuan" dan akan dilakukan dua kali, tes pertama adalah Pretest digunakan untuk mengetahui pengetahuan awal dan tes kedua adalah Posttest digunakan untuk mengetahui pengetahuan akhir setelah mendapat perlakuan dari masingmasing kelas yaitu kelas eksperimen dan kelas control.

Dalam melakukan analisis data dalam penelitian ini, langkah pertama yaitu mendeskripsikan data, kemudian uji persyaratan analisis yang terdiri dari uji normalitas dan uji homogenitas. Untuk pengujian hipotesis menggunakan t-test.

\section{HASIL DAN DISKUSI}

\section{HASIL}

Tes hasil belajar berupa pretest dan posttest terdiri dari soal pilihan berganda. Tes ini diberikan secara daring melalui google form. Adapun indicator yang ingin dicapai adalah mahamahasiswa dapat menguasai konsep dan prinsip integral merupakan anti derivatif. Bentuk soal pretest dan posttest adalah sama yaitu terdiri dari sepuluh (10) soal pilihan ganda.

Penelitian ini menggunakan responden kelas PSPM 21 D sebagai kelas control dengan jumlah mahamahasiswa 45 dan PSPM 21 F sebagai kelas eksperimen dengan jumlah mahamahasiswa 44 orang. Data dalam penelitian ini terdiri dari data tes awal (pretest) dan data tes akhir (posttest).

Adapun data hasil pretest dan posttest pada kelas Eksperimen dan control dapat dilhat pada table berikut.

Tabel 1 Distribusi Frekuensi data pretest kelas eksperimen

\begin{tabular}{|l|l|l|}
\hline Nilai & Frekuensi & Frekuensi Relatif (\%) \\
\hline
\end{tabular}




\begin{tabular}{|l|l|l|}
\hline 40 & 5 & 11,1 \\
\hline 44 & 15 & 33,3 \\
\hline 48 & 11 & 24,4 \\
\hline 52 & 10 & 22,3 \\
\hline 56 & 4 & 8,9 \\
\hline Jumlah & 45 & 100,00 \\
\hline
\end{tabular}

Berdasarkan table di atas diperoleh nilai tertinggi sebesar 56, nilai terendah sebesar 40 , modus sebesar 44, median sebesar 48 , nilai ratarata sebesar 47,38; dan simpangan baku sebesar 4,62.

Tabel 2 Distribusi Frekuensi data pretest kelas control

\begin{tabular}{|l|l|l|}
\hline Nilai & Frekuensi & Frekuensi Relatif (\%) \\
\hline 32 & 1 & 2,2 \\
\hline 36 & 2 & 4,5 \\
\hline 40 & 5 & 11,4 \\
\hline 44 & 7 & 15,9 \\
\hline 48 & 20 & 45,5 \\
\hline 52 & 7 & 15,9 \\
\hline 56 & 1 & 2,3 \\
\hline 60 & 1 & 2,3 \\
\hline Jumlah & 44 & 100,00 \\
\hline
\end{tabular}

Berdasarkan table di atas diperoleh nilai tertinggi sebesar 60, nilai terendah sebesar 32 , modus sebesar 48 , median sebesar 48 , nilai rata-rata sebesar 46,97 ; dan simpangan baku sebesar 5,33.

Berdasarkan nilai rata - rata pada table 1 dan table 2 dapat disimpulkan bahwa tidak ada perbedaan yang signifikan antara kelas eksperimen dan kelas kontrol

Tabel 3 Distribusi Frekuensi data posttest kelas eksperimen

\begin{tabular}{|l|l|l|}
\hline Nilai & Frekuensi & Frekuensi Relatif (\%) \\
\hline 64 & 1 & 2,2 \\
\hline 68 & 2 & 4,4 \\
\hline 72 & 10 & 22,2 \\
\hline 80 & 21 & 46,8 \\
\hline 84 & 9 & 20 \\
\hline 90 & 2 & 4,4 \\
\hline Jumlah & 45 & 100,00 \\
\hline
\end{tabular}


Berdasarkan table di atas diperoleh nilai tertinggi sebesar 90, nilai terendah sebesar 64 , modus sebesar 80 , median sebesar 80 , nilai ratarata sebesar 78,58 ; dan simpangan baku sebesar 3,61.

Tabel 4 Distribusi Frekuensi data posttest kelas kontrol

\begin{tabular}{|l|l|l|}
\hline Nilai & Frekuensi & Frekuensi Relatif (\%) \\
\hline 56 & 2 & 45,6 \\
\hline 60 & 6 & 13,6 \\
\hline 64 & 10 & 22,7 \\
\hline 76 & 14 & 31,8 \\
\hline 80 & 12 & 27,3 \\
\hline Jumlah & 44 & 100,00 \\
\hline
\end{tabular}

Berdasarkan table di atas diperoleh nilai tertinggi sebesar 76, nilai terendah sebesar 56 , modus sebesar 76, median sebesar 76, nilai rata-rata sebesar 71,23; dan simpangan baku sebesar 4,54.

\subsubsection{Hasil Uji Hipotesis}

Pengujian hipotesis dilakukan untuk mengetahui apakah ada perbedaan pengetahuan mahamahasiswa materi integral antara kelas kontrol dan kelas eksperimen. Kelas kontrol tanpa media pembelajaran padlet sedangkan kelas eksperimen diajar dengan menggunakan media pembelajaran padlet. Uji hipotesis yang digunakan adalah uji-† dua sampel independen (tidak berkolerasi), karena data diperoleh dari dua kelas yang berbeda.

Hipotesis nol $(\mathrm{Ho})$ dan hipotesis alternatif $(\mathrm{Ha})$ penelitian ini berbunyi :

$\mathrm{Ho}=$ Tidak terdapat perbedaan pengetahuan mahamahasiswa yang menggunakan media pembelajaran padlet dengan mahamahasiswa yang belajar tanpa menggunakan media pembelajaran padlet.

$\mathrm{Ha}=$ Terdapat perbedaan pengetahuan mahamahasiswa yang menggunakan media pembelajaran padlet dengan mahamahasiswa yang belajar tanpa menggunakan media pembelajaran padlet.

Kriteria penerimaan $\mathrm{Ho}$ dan $\mathrm{Ha}$ adalah jika thitung lebih besar dari ttabel maka Ho ditolak dan Ha diterima, akan tetapi jika thitung lebih kecil dari ttabel maka Ho diterima dan $\mathrm{Ha}$ ditolak.

Hasil analisis uji hipotesis menunjukkan bahwa harga thitung $=2,46$. Kemudian harga thitung dibandingkan dengan harga tabel dengan taraf signifikan $5 \%$ dan $\mathrm{dk}=\mathrm{n}-1$ atau $\mathrm{dk}=$ $45-1$. Sehingga didapat $d k=45-1=44$ dan tabel $=2,015$. Sehingga diperoleh keputusan bahwa Ho ditolak dan Ha diterima. Berdasarkan hasil uji hipotesis dapat diketahui bahwa terdapat perbedaan prestasi belajar mahamahasiswa yang 
menggunakan media pembelajaran padlet dengan mahamahasiswa yang belajar tanpa menggunakan media pembelajaran padlet.

Tabel 5 Hasil Uji Hipotesis

\begin{tabular}{|c|c|c|c|c|c|}
\hline Hipotesis & thitung & $\mathbf{t}_{\text {tabel }}$ & $\mathbf{d k}$ & Taraf signifikansi & Kesimpulan \\
\hline Hipotesis & 2,46 & 2,015 & 44 & $\mathbf{5 \%}$ & $\begin{array}{c}\text { Ho ditolak dan } \\
\text { Ha diterima }\end{array}$ \\
\hline
\end{tabular}

\section{1,2 Hasil penelitian yang relevan}

Adapun penelitian yang relevan terhadap penelitian ini adala penelitian yang dilakukan oleh Siskiliani dan Jeranah(2021) yang berjudul " PENGARUH PENGGUNAAN MODEL PEMBELAJARAN E-LEARNING DENGAN MENGGUNAKAN MEDIA PADLET TERHADAP HASIL BELAJAR MATEMATIKA PADA MAHASISWA SMA YP PGRI 3 MAKASSAR" . Dalam penelitian diperoleh bahwa hasil belajar matematika mahasiswa yang diajar dengan model pembelajaran e-learning menggunakan media padletlebih tinggi dari pada hasil belajar yang diajar dengan model pembelajaran langsung". Respon mahasiswa terhadap proses pembelajaran cukup positif.

Dan juga penelitian yang telah dilakukan oleh Prasetyo Widyanto dkk (2021)yang berjudul " Pembelajaran Daring Menggunakan Model Pembelajaran Think Talk Write Berbantuan Padlet untuk Meningkatkan Hasil Belajar Mahasiswa". Dalam penelitian ini diperoleh bahwa model Think Talk Write berbantuan Padlet dapat meningkatkan hasil belajar mahasiswa pada pembelajaran daring. Rata-rata hasil belajar mahasiswa pada tiap siklus selalu meningkat. Awalnya hasil tes kemampuan menalar mahasiswa pada Pra Siklus hanya mencapai 53,6, kemudian terjadi peningkatan pada siklus I menjadi 65,7, pada Siklus II juga mengalami peningkatan menjadi 77,8.

\section{PEMBAHASAN}

Berdasarkan hasil penelitian yang dilakukan di FMIPA Universitas Negeri Medan jurusan Pendidikan Matematika pada kelas PSPM 21D dan PSPM 21F dapat diketahui bahwa sebelum mendapat perlakuan yang berbeda, tingkat pengetahuan mahamahasiswa pada kedua kelas tersebut hampir sama. Hal ini dapat dilihat dari hasil pretest kedua kelas tersebut. Kelas PSPM 21D sebagai kelas kontrol memiliki ratarata pretest sebesar 46,97, sedangkan kelas PSPM 21F sebagai kelas eksperimen memiliki rata-rata nilai pretest sebesar 47,38. Dengan melihat rata-rata nilai kedua kelas tersebut dapat dikatakan bahwa kemampuan awal dari kelas kontrol dan eksperimen tidak terdapat perbedaan yang signifikan.

Dari pengujian hipotesis dapat diketahui bahwa kelas eksperimen dan kelas kontrol sama-sama mengalami peningkatan pengetahuan mahamahasiswa. Akan tetapi peningkatan pengetahuan kelas eksperimen lebih tinggi dibandingkan 
peningkatan pengetahuan pada kelas kontrol. Hal ini terlihat dari hasil nilai postest kelas eksperimen sebesar 78,58 yang lebih tinggi dibandingkan nilai posttest kelas kontrol yaitu sebesar 71,23. Kelompok eksperimen yang mendapat perlakuan dengan menggunakan media padlet dalam pembelajaran lebih baik hasilnya dibandingkan dengan kelompok kontrol yang tidak mendapat perlakuan. Dengan demikian peningkatan pengetahuan mahamahasiswa pada kelompok eksperimen disebabkan adanya penggunaan media pembelajaran padlet. Karena dengan penggunakan media pembelajaran padlet dapat menarik perhatian mahamahasiswa untuk lebih aktif dalam mengerjakan LKPD dan lebih memahami materi yang disampaikan dalam padlet.

Perbandingan prestasi belajar kelas eksperimen dan kelas kontrol dapat dilihat pada tabel berikut :

Tabel 6 Nilai rata - rata kelas Eksperimen dan Kelas Kontrol

\begin{tabular}{|c|c|c|}
\hline \multirow{2}{*}{} & \multicolumn{2}{|c|}{ Nilai Rata - rata } \\
\cline { 2 - 3 } & Pretest & Posttest \\
\hline Eksperimen & 47,38 & 78,58 \\
\hline Kontrol & 46,97 & 71,23 \\
\hline
\end{tabular}

Nilai rata-rata di atas dapat pula dilihat dalam bentuk histogram perbandingan prestasi belajar kelas eksperimen dan kelas kontrol sebagai berkut :

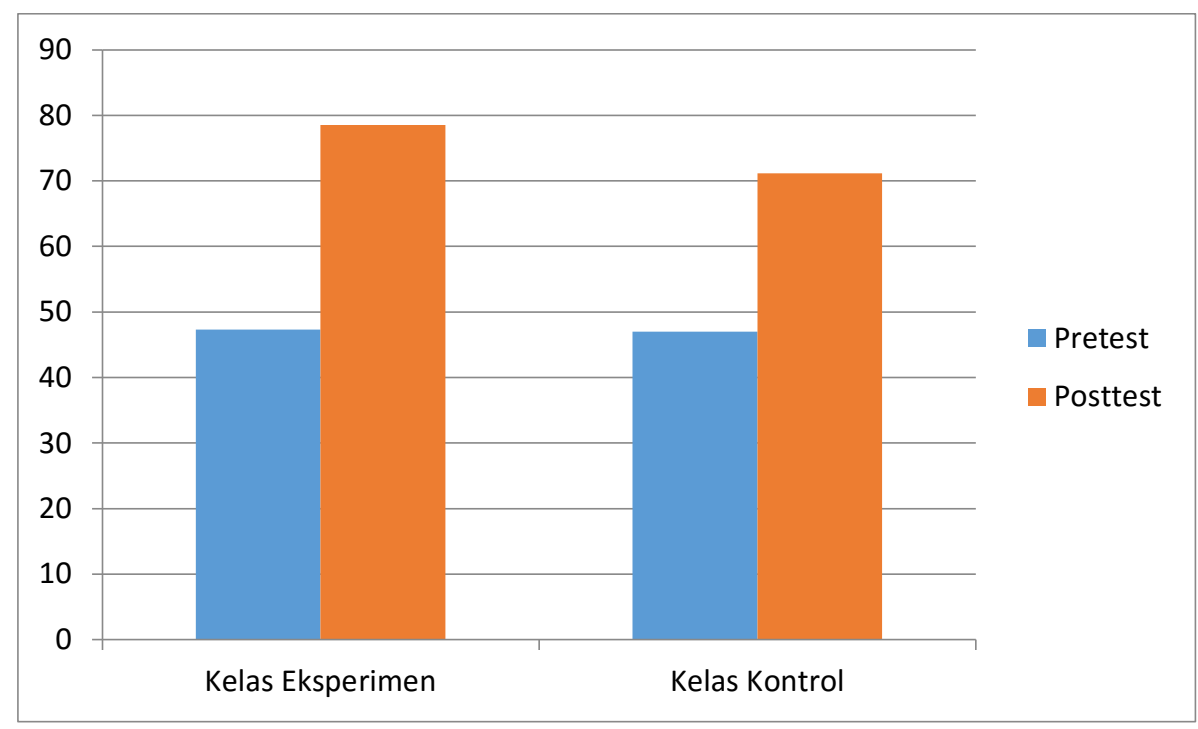

Gambar 1. Histogram Perbandingan pengetahuan mahasiswa Kelas Eksperimen dan Kelas Kontrol

\subsubsection{Efektivitas Media Pembelajaran Padlet}

Hasil penelitian menunjukan bahwa rata-rata nilai awal kelas eksperimen sebelum pembelajaran menggunakan media padlet (O1) sebesar 47,38. Rata-rata nilai akhir kelas eksperimen setelah pembelajaran menggunakan media pembelajaran padlet 
(O3) sebesar 75,58. Rata-rata nilai awal kelas kontrol sebelum pembelajaran tanpa menggunakan media pembelajaran padlet (O2) sebesar 47,69. Rata-rata nilai akhir kelas kontrol setelah pembelajaran tanpa menggunakan media digital (O4) sebesar 71,23. Berdasarkan data diatas laju peningkatan nilai kelas eksperimen dan kelas kontrol dapat dilihat bahwa nilai akhir kelas eksperimen lebih besar dari nilai akhir kelas kontrol. Sehingga dapat disimpulkan bahwa penggunaan media pembelajaran padlet pada mata kuliah Integral jauh lebih efektif dari pada tanpa menggunakan media pembelajaran padlet.

\section{KESIMPULAN}

Berdasarkan hasil penelitian dan pembahasan yang telah disampaikan, maka dapat diambil kesimpulan sebagai berikut : 1) Berdasarkan nilai pretest diketahui bahwa nilai rata-rata kelas kontrol sebesar 46.97 dan nilai posttes 71,234. Sehingga dapat dikatakan ada peningkatan prestasi siswa setelah pembelajaran tanpa aplikasi padlet. 2) Berdasarkan nilai pretest diketahui bahwa nilai rata-rata kelas eksperimen sebesar 47,38 dan nilai posttes 78,58. Sehingga dapat dikatakan ada peningkatan pengetahuan siswa setelah pembelajaran menggunakan aplikasi padlet. 3) Peningkatan pengetahuan mahasiswa kelas eksperimen lebih besar atau lebih cepat daripada peningkatan pengetahuan mahasiswa kelas kontrol yaitu 78,58 > 71,23. 4) Berdasarkan peningkatan nilai kelas eksperimen dan kelas kontrol dapat dilihat bahwa perbedaan laju peningkatan nilai kelas eksperimen dan kelas kontrol sebesar 7,35 lebih besar kelas eksperimen, maka dapat disimpulkan bahwa terdapat efektivitas penggunaan aplikasi padlet pada materi integral.

\section{REFERENSI}

Afifatu Rohmawati (2015), Efektivitas Pembelajaran. Jurnal Pendidikan Usia Dini. Volume 9, Edisi 1. https://media.neliti.com/media/publications/118596-IDefektivitas-pembelajaran.pdf

Ahmad. Nuzula, Firdausi. Makky, Khalid. 2020. Efektivitas Pembelajaran Daring Dengan Menggunakan Google Classroom Pelajaran Matematika Di Madrasah Ali Darul Falah Batu Jangkih. EL-HIKAM: Jurnal Pendidikan dan Kajian Keislama. Universitas Bumi Gora Mataram, IAIN Nurul hakim. Volume XIII, Nomor 1.

Albert Efendi Pohan, 2020. Konsep Pembelajaran Daring Berbasis Pendekatan Ilmiah. CV. Ssarnu Untung: Jawa Tengah

Arnesi Novita Dan Hamid K Abdul. 2015. "Penggunaan Media Pembelajaran Online Offline Dan Komunikasi Interpersonal Terhadap Hasil Belajar Bahasa Inggris". Jurnal Teknologi Informasi \& Komunikasi Dalam Pendidikan, Vol. 2. No. 1.

Aziz, Abdul dkk. 2020. Efektivitas Pembelajaran Daring Saat Menghadapi Pandemi Virus Corona.. Program Studi Pendidikan Matematika Fakultas Keguruan Dan IImu Pendidikan Universitas Singaperbangsa Karawang. 
Cindi Vatika Sari, 2021. Efektivitas Pelaksanaan Program Mappadeceng di Dinas Sosial Kabupaten Soppeng. Skripsi Universitas Muhammadiyah Makassar. https://digilibadmin.unismuh.ac.id/upload/13608-Full Text.pdf

Desi Yeni Ratnasari. 2021. Pengaruh Model Pembelajaran Flipped Classroom Menggunakan Aplikasi Padlet Terhadap Kemampuan Berfikir Tingkat Tinggi $\begin{array}{llll}\text { Peserta Didik } & \text { Kelas } & 10 & \text { Sma. }\end{array}$ http://repository.radenintan.ac.id/14052/1/SKRIPSI\%201-2.pdf

Dewitt D, Alias N, Siraj S. Collaborative learning: Interactive debates using Padlet in a higher education institution. http://eprints.um.edu.my/13630/1/971662 JournalSubmission_WN.pdf

Dr. Nofrion, M.Pd, "padlet sebagai platform pembelajaran daring pada masa pandemi.

(file:///C:/Users/IDEAPA 1/AppData/Local/Temp/LANGKAH\%20KERJA\%20PADLE T\%20SEBAGAI\%20PLATFORM\%20PEMBELAJARAN\%20DARING.pdf)

Goldschmidt, K. (2020). The Covid-19 Pandemic: Technology use to support the wellbeing of children. Journal of Pediatric Nursing, 88-90

ISTE Standards. 2020. (https://www.iste.org/standards)

Kor, H., Aksoy, H., \& Eerbay, H. (2014). Comparison of the Proficiency Level of the Course Materials (Animations, Videos, Simulations, E-Books) Used In Distance Education. Procedia - Social and Behavioral Sciences, 141, 854-860. Retrieved from https://doi.org/10.1016/j.sbspro.2014.05.150

Lenar, S., Artur, F., Ullubi, S., \& Nailya, B. (2014). Problems And Decision In The Field Of Distance Education. Procedia - Social and Behavioral Sciences, 131, 111-117. Retrieved from https://doi.org/10.1016/j.sbspro.2014.04.088

Lestari G, Mahbubah A, Masykuri MF. Pembelajaran Bahasa Arab Digital dengan Menggunakan Media Padlet di Madrasah Aliyah Billingual Batu. Proceeding Int Conf Islam Educ. 2019;4(1):238-244 http://conferences.uinmalang.ac.id/index.php/icied/article/view/1092/424

Prasetyo Widyanto dkk.2021.Artikel:Pembelajaran Daring Menggunakan Model Pembelajaran Think Talk Write Berbantuan Padlet untuk Meningkatkan Hasil Belajar Mahasiswa.Jurnal UNNES, $v$ 1, hal 60-65

Rulitawati, Husein Ritonga, Lias Hasibuan, 2020. Model Pengelolaan Kinerja Guru. Tunas Gemilang Press: Palembang.

R. Gilang K. Pelaksanaan Pembelajaran daring di Era Covid-19. Lutfi Gilang: Banyumas, Jawa tengah.

Sugiyono. (2019). Metode Penelitian Kuantitatif, Kualitatif, dan R\&D. Bandung: CV Alfabeta. 
Siskiliani dan Jeranah.2021.Artikel: Pengaruh Penggunaan Model Pembelajaran ELearning Dengan Menggunakan Media Padlet Terhadap Hasil Belajar Matematika Pada Mahasiswa Sma Yp Pgri 3 Makassar. Jurnal Pendidikan Matematika, v. 1, n. 1, hal. 181-189, Mei 2021

Wan Noor Hazlina Wan Jusoh and others, "Persepsi Pelajar Terhadap Penggunaan Video Dan Padlet (Pvdp) Dalam Pengajaran Dan Pembelajaran Subjek Pemikiran Dan Tamadun Islam", E-Academia Journal, 8.2 (2019), 1-7 https://myims.mohe.gov.my/index.php/JeA/article/view/7378/2986

Wilder-Smith, A., \& Freedman, D. O. (2020). Isolation, quarantine, social distancing and community containment: pivotal role for old-style public health measures in the novel coronavirus (2019-nCoV) outbreak. Journal of Travel Medicine, 1-4. 